\title{
Regulation by Fasting of Rat Insulin-like Growth Factor I and Its Receptor Effects on Gene Expression and Binding
}

\author{
William L. Lowe, Jr., Martin Adamo, Haim Werner, Charles T. Roberts, Jr., and Derek LeRoith \\ Diabetes Branch, National Institute of Diabetes and Digestive and Kidney Diseases, National Institutes of Health, \\ Bethesda, Maryland 20892
}

\begin{abstract}
We have examined, in liver and extrahepatic tissues, the effects of fasting on total insulin-like growth factor I (IGF-I) mRNA levels, on levels of different IGF-I mRNAs generated by alternative splicing of the primary IGF-I transcript, and on IGF-I receptor binding and mRNA levels. A 48-h fast decreased total IGF-I mRNA levels by $\sim 80 \%$ in lung and liver, $\sim 60 \%$ in kidney and muscle, and only $\sim 30-40 \%$ in stomach, brain, and testes. In heart, IGF-I mRNA levels did not change. The levels of the different splicing variants, however, were essentially coordinately regulated within a given tissue. Specific ${ }^{125}$ I-IGF-I binding in lung, testes, stomach, kidney, and heart was increased by fasting by $\sim 30-100 \%$, whereas in brain ${ }^{125}$ I-IGF-I binding did not change in response to fasting. In tissues in which fasting increased IGF-I receptor number, receptor mRNA levels increased $\sim$ 1.6- to 2 .5-fold, whereas when IGF-I receptor number was unchanged in response to fasting, receptor mRNA levels did not change. These data demonstrate that the change in IGF-I and IGF-I receptor mRNA levels during fasting is quantitatively different in different tissues and suggest that regulation of IGF-I and IGF-I receptor gene expression by fasting is discoordinate.
\end{abstract}

\section{Introduction}

Insulin-like growth factor I (IGF-I) ${ }^{1} /$ somatomedin-C is a mitogenic polypeptide structurally related to insulin. Sequence analyses of mature IGF-I peptide purified from plasma demonstrated that mature IGF-I, like insulin, contains B, C, and A domains, but that, unlike proinsulin, a carboxy-terminal D domain is present as well (1). Elucidation of IGF-I cDNA sequences confirmed the peptide sequence and also predicted the presence in IGF-I prohormone of an additional $E$ domain which is a carboxy-terminal extension of the D domain (2-4). Presumably, the peptide that is translated from this region, the

Dr. Lowe's present address is Department of Medicine, Veterans Administration Medical Center, College of Medicine, University of Iowa, Iowa City, IA.

Address correspondence to Dr. Derek LeRoith, Building 10, Room 8S243, Diabetes Branch, NIDDK, National Institutes of Health, 9000 Rockville Pike, Bethesda, MD 20892.

Received for publication 22 September 1988 and in revised form 13 March 1989.

1. Abbreviations used in this paper: GH, growth hormone; IGF-I, insulin-like growth factor $\mathrm{I} ; K_{d}$, binding affinity; $R_{0}$, receptor concentration.

The Journal of Clinical Investigation, Inc.

Volume 84, August 1989, 619-626
E-peptide, is cleaved during the processing of IGF-I prohormone into mature IGF-I peptide.

Determination of the sequences of rat IGF-I CDNAs and of the partial organization of the rat IGF-I gene has demonstrated that multiple species of IGF-I mRNA are generated by alternative splicing of the primary IGF-I transcript (4-6). These mRNAs contain one of at least three alternative 5 '-untranslated regions that are expressed in a tissue-specific manner and are differentially regulated by growth hormone $(\mathrm{GH})(5,7,8)$. The physiological significance of these different 5'-untranslated regions is not known, but sequence analyses of these regions suggested that they may encode alternative, extended signal peptides and that at least one of them may be subject to translational control (5). In addition to this heterogeneity in the $5^{\prime}$-untranslated region, alternative splicing also results in heterogeneity in the region encoding the E-peptide of IGF-I prohormone in that a 52-base insert is either present or absent in IGF-I mRNAs resulting in the generation of alternative E-peptides (4). Again, the physiological role of these E-peptides either as part of the prohormone or as free E-peptides is not yet known.

IGF-I, through its interaction with specific IGF-I receptors, mediates many of the growth-promoting effects of $\mathrm{GH}$, and GH is one of the primary regulators of plasma IGF-I levels (9). The nutritional status of an animal also appears to regulate plasma IGF-I levels in that fasting as well as a diet deficient in energy and/or protein result in decreased plasma IGF-I levels (for review see references 10 and 11). The mechanism for the reduction in plasma IGF-I levels in response to alterations in diet has not been fully elucidated, but nutritional alterations in the rat typically result in a slight decrease in serum GH levels $(12,13)$. More importantly, however, fasting decreases hepatic GH binding (11), and the response of plasma IGF-I concentrations to $\mathrm{GH}$ injection is blunted in protein-malnourished and fasted rats as compared with fed controls $(10,14)$, suggesting that such nutritional alterations can result in a GH-resistant state.

Hepatic production of IGF-I appears to account for the majority of circulating IGF-I (15), and a recent study has demonstrated decreased IGF-I mRNA levels in livers obtained from fasted as opposed to fed rats (16). IGF-I is also produced, however, in extrahepatic tissues (17), where, in addition to apparently being involved in tissue repair and regeneration $(18-20)$, it may also serve specialized functions $(21-24)$. This suggests that the regulation of IGF-I production in different tissues may be under differential control.

In this study we have evaluated the nutritional regulation of total IGF-I mRNA levels in liver and extrahepatic tissues to determine if the regulation of IGF-I mRNA levels is coordinate or discoordinate in different tissues. Furthermore, we have examined the nutritional regulation of the levels of the splicing variants of the rat IGF-I gene. Finally, since IGF-I 
action is mediated by the interaction of IGF-I with the IGF-I receptor, we have also examined the effect of fasting on IGF-I binding and on the levels of mRNA encoding the IGF-I receptor.

\section{Methods}

Preparation of RNA. Male Sprague-Dawley rats were either fasted for $48 \mathrm{~h}$, fed ad lib. for $48 \mathrm{~h}$, or fasted for $48 \mathrm{~h}$ and then refed for $24 \mathrm{~h}$. All groups were allowed free access to water during the course of the study. At the end of the study period RNA was prepared from tissues of individual rats using a modification of the method of Cathala et al. (25) as described (26). The RNA was quantified by determining absorbance at $260 \mathrm{~nm}$. The integrity of the RNA and the accuracy of the quantitation were confirmed by comparing the ethidium bromide stain of the $28 \mathrm{~S}$ and $18 \mathrm{~S}$ ribosomal RNA bands after size-separating $15 \mu \mathrm{g}$ of total RNA by agarose gel electrophoresis, which was performed as described previously (26).

Hybridization probes. For hybridization to Northern blots, a 700bp human IGF-I receptor cDNA (kindly provided by Dr. Axel Ullrich, Genentech Corp, South San Francisco, CA) that contained 35 bp of 5 -untranslated region and 665 bp of coding region was used (27).

For the solution hybridization/RNase protection assays used to determine IGF-I mRNA levels, two different riboprobe vectors that have been described previously were used $(8,28)$. Briefly, one construct contained a 322-bp IGF-I cDNA that included 98 bp of the class A 5'-untranslated region and $224 \mathrm{bp}$ of coding region corresponding to the pre, B, C, and part of the A domains (8). Antisense RNAs generated from this construct allow the simultaneous detection of IGF-I mRNAs with the three previously described 5 -untranslated regions (arbitrarily termed class A, B, and C 5'-untranslated regions) known to be present in IGF-I mRNAs (8). The other construct contained a 376-bp IGF-I cDNA containing sequences encoding part of the $A$ domain, the entire $\mathrm{D}$ and $\mathrm{E}$ domains (including the 52-bp insert present in some IGF-I mRNAs), and part of the 3'-untranslated region. Antisense RNAs generated from this linearized construction permit the simultaneous detection of IGF-I mRNAs without (IGF-Ia) and with (IGF-Ib) the 52base insert (28). For determination of IGF-I receptor mRNA levels by the solution hybridization/RNase protection assay, a 575-bp rat IGF-I receptor cDNA isolated from a rat granulosa cell cDNA library (Werner, H., manuscript in preparation) was used. This cDNA was ligated into a pGEM-3 vector. The orientation of the cDNA in the vector was determined by sequencing, and the vector was linearized with Hind III to allow for the generation of IGF-I receptor antisense RNAs with T7 RNA polymerase.

Solution hybridization/RNase protection assay. Protection assays were performed as previously described (8). Briefly, labeled IGF-I and IGF-I receptor antisense RNAs were synthesized from the constructions described above using [ $\alpha^{32}$ P]UTP. $20 \mu \mathrm{g}$ of total RNA was hybridized with $\sim 200,000 \mathrm{cpm}$ of labeled antisense RNA for $\sim 16 \mathrm{~h}$ at $45^{\circ} \mathrm{C}$ in $75 \%$ formamide $/ 400 \mathrm{mM} \mathrm{NaCl}$. After hybridization the mixture was added to RNase digestion buffer containing $40 \mu \mathrm{g} / \mathrm{ml}$ RNase A (Sigma Chemical Co., St. Louis, MO) and $2 \mu \mathrm{g} / \mathrm{ml} \mathrm{RNase} \mathrm{T1} \mathrm{(Phar-}$ macia Fine Chemicals, Piscataway, NJ) and incubated for $1 \mathrm{~h}$ at $30^{\circ} \mathrm{C}$. Protected hybrids were isolated by ethanol precipitation and size-separated on an $8 \%$ polyacrylamide/8 $\mathrm{M}$ urea denaturing gel. Quantification of the RNA bands was performed with an ultrascan laser densitometer (LKB Instruments, Inc., Gaithersburg, MD) coupled to an AT\&T computer, or a scanning densitometer (model GS300; Hoefer Scientific Instruments, San Francisco, CA).

RNA gel electrophoresis and Northern blot analysis. Total RNA was size-separated by agarose gel electrophoresis and transferred and fixed to a nylon membrane (Gene Screen; New England Nuclear, Boston, MA) as described (26). The IGF-I receptor cDNA probes were labeled using a modification of the random priming technique (29) as described previously (26) to a sp act of $5-9 \times 10^{8} \mathrm{cpm} / \mu \mathrm{g}$ DNA. Hybridizations were performed as described previously (26).
Preparation of crude membranes. Crude membranes from tissues of rats either fed ad lib. or fasted for $48 \mathrm{~h}$ were prepared as described by Havrankova et al. (30) with some modifications. Rats were killed by decapitation and tissues were removed and frozen in liquid $\mathrm{N}_{2}$. Tissues were homogenized in $20 \mathrm{vol}$ (by weight) of ice-cold $1 \mathrm{mM} \mathrm{NaHCO}$ containing $10 \mu \mathrm{g} / \mathrm{ml}$ leupeptin, $1 \mathrm{TIU} / \mathrm{ml}$ aprotinin, and $2 \mathrm{mM} \mathrm{PMSF}$ using 20 strokes of a motor-driven glass/teflon device (liver, brain, lung, kidney, and testes) or a polytron (stomach, heart, and skeletal muscle). Homogenates were centrifuged at $600 \mathrm{~g}$ for $10 \mathrm{~min}$ at $4^{\circ} \mathrm{C}$ and the resulting supernatants were centrifuged at $20,000 \mathrm{~g}$ for $30 \mathrm{~min}$ at $4^{\circ} \mathrm{C}$. The pellets from this centrifugation step were washed once in homogenization buffer and recentrifuged. The final membrane pellets were resuspended in $\mathrm{Ca}^{2+}$-free $\mathrm{Krebs}-\mathrm{Ringer}$ phosphate buffer (KRP), $\mathrm{pH} 7.8$, and stored frozen at $-70^{\circ} \mathrm{C}$. Membrane protein concentrations were determined according to the method of Lowry et al. (31).

${ }^{125}$ I-IGF-I binding assays. Binding of ${ }^{125}$ I-IGF-I to crude membranes was determined using the method described for insulin binding by Havrankova et al. (30) with modifications. $50 \mu \mathrm{l}$ of $\mathrm{Ca}^{2+}$-free $\mathrm{KRP} / 0.1 \% \mathrm{BSA}, \mathrm{pH} 7.6$, either without or with varying concentrations of unlabeled [ [ $\left.{ }^{59} \mathrm{Thr}\right]$ IGF-I (Amgen Biologicals, Thousand Oaks, CA), were added to $50 \mu \mathrm{l} \mathrm{Ca}{ }^{2+}$-free KRP with $3 \mathrm{mg} / \mathrm{ml}$ bacitracin and $3 \%$ BSA, pH 8.0, containing ${ }^{125}$ I-IGF-I (Amersham Corp., Arlington Heights, IL). $50 \mu \mathrm{l}$ of membrane suspension containing $\sim 60 \mu \mathrm{g}$ protein was then added and incubations were conducted for $18 \mathrm{~h}$ at $4^{\circ} \mathrm{C}$. The final ${ }^{125} \mathrm{I}-\mathrm{IGF}-\mathrm{I}$ concentration was $\sim 0.15 \mathrm{ng} / \mathrm{ml}$. Membranebound and free ${ }^{125} \mathrm{I}-\mathrm{IGF}-\mathrm{I}$ were separated by centrifugation at $12,000 \mathrm{~g}$ for $10 \mathrm{~min}$ and aspirating the supernatants. Membrane pellets were washed once with $200 \mu$ lice-cold $\mathrm{Ca}^{2+}$-free $\mathrm{KRP}, \mathrm{pH} 7.8$, and the tips of the centrifuge tubes were excised. ${ }^{125}$ I-Radioactivity was determined in a gamma counter. Nonspecific binding was defined as the counts of ${ }^{125}$ I-IGF-I remaining associated with membranes in the presence of 1 $\mu \mathrm{g} / \mathrm{ml}$ unlabeled IGF-I, and was subtracted from total binding to yield specific binding. Data from competition/inhibition experiments were analyzed according to the method of Scatchard (32) to determine binding affinities $\left(K_{\mathrm{d}}\right)$ and receptor concentrations $\left(R_{0}\right)$. Degradation of ${ }^{125}$ I-IGF-I in the binding assays was assessed as the TCA precipitability of aliquots of the supernatants from binding assays.

Statistical analysis. The significance of differences was determined using analysis of variance. For comparison of IGF-I receptor mRNA levels, analysis of variance was performed on logarithmic transformations of densitometric data.

\section{Results}

Total IGF-I mRNA levels in the tissues from rats fasted for 48 $\mathrm{h}$ or fed ad lib. were determined using a solution hybridization/RNase protection assay. The relative change in IGF-I mRNA levels in fasted as compared with fed animals is depicted in Fig. 1. Consistent with a previous report (16), IGF-I mRNA levels decreased markedly in the liver. In addition, in lung IGF-I mRNA levels also decreased by $\sim 80 \%$ in response to fasting. In muscle and kidney the response of IGF-I mRNAs to fasting was intermediate with levels decreasing to $\sim 40 \%$ of control levels. In stomach, testes, and brain, on the other hand, IGF-I mRNA levels decreased by only $\sim 30-40 \%$ in response to fasting. In heart the levels of IGF-I mRNA in the fasted and fed animals were essentially identical. In lung and liver refeeding for $24 \mathrm{~h}$ resulted in a $\sim 2.5$-fold increase in IGF-I mRNA levels over fasting levels (data not shown). In muscle, kidney, stomach, and testes refeeding increased IGF-I mRNA levels 1.4- to 1.5-fold over fasting levels, while in heart and brain, refeeding did not affect IGF-I mRNA levels (data not shown). These data demonstrate that the response of IGF-I mRNA levels to fasting is quantitatively different in different tissues.

Solution hybridization/RNase protection assays in which 


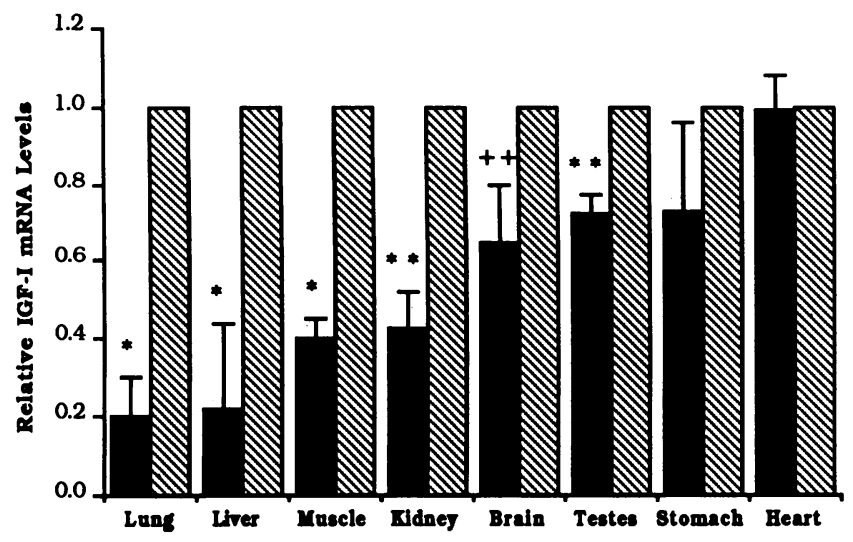

Figure 1. Relative IGF-I mRNA levels in tissues from fasted and fed rats. IGF-I mRNA levels in tissues from the fasted (solid bars) and fed (hatched bars) rats were determined using a solution hybridization/RNase protection assay. For each tissue the assay was performed with the two different IGF-I antisense RNAs described in Methods, one that detects IGF-I mRNAs with the different 5'-untranslated regions and one that detects IGF-I mRNAs with and without the 52-base insert in the region encoding the E-peptide. Total IGF-I mRNA levels within a given tissue were determined by combining the contribution of the different protected bands within that tissue. The values shown represent the relative IGF-I mRNA levels in fasted as compared with fed tissue. In each case the level of IGF-I mRNA in the fed tissue was adjusted to 1.0 and the level in the fasted tissue was normalized accordingly. The values do not reflect, therefore, tissue to tissue differences in IGF-I mRNA levels. The value for each tissue represents the mean of the value in three different RNA preparations prepared from three different animals.

*, $P<0.005$; ${ }^{* *}, P<0.0025 ;++, P<0.025$.

an antisense RNA complementary to the class A 5 '-untranslated region and coding region was used allowed for the simultaneous quantitation of the levels of IGF-I mRNAs with different 5'-untranslated regions (8). The IGF-I mRNAs with different 5 -untranslated regions are represented as protected bands 322,297 , and 242 bases in length, corresponding to IGF-I mRNAs with the class A, B, and C 5'-untranslated regions, respectively (Fig. 2). In most tissues in which more than one IGF-I 5'-untranslated region variant was present, the levels of these different IGF-I mRNAs appeared to be coordinately regulated by fasting (Fig. 2 and Table I). In lung, the levels of the IGF-I mRNA variants present also decreased with fasting, but the magnitude of change of the IGF-I mRNA with the class $C$ 5'-untranslated region was greater than the magnitude of change of the IGF-I mRNA with the class A 5'-untranslated region.

Solution hybridization/RNase protection assays performed with an antisense RNA complementary to the region encoding a portion of the A domain, the entire $\mathrm{D}$ and $\mathrm{E}$ domains, and a portion of the 3 '-untranslated region simultaneously quantitated IGF-I mRNAs without (IGF-Ia) and with (IGF-Ib) the 52-base insert (Table II). IGF-Ib and IGF-Ia mRNAs were represented by protected bands 376 and 224 bases in length, respectively (data not shown). Consistent with previous results, IGF-Ib mRNA was present in low abundance in all tissues, but liver had proportionally more IGF-Ib mRNA than the other tissues (28). In all of the tissues surveyed the levels of IGF-Ia and IGF-Ib mRNA were coordinately regulated by fasting, except for the liver, in which the change in the levels of IGF-Ib mRNA was much greater than the change in levels of IGF-Ia mRNA (Table II).

Since IGF-I mediates its bioeffects through the IGF-I receptor, and IGF-I action is a function of both ligand and receptor concentration, the effect of fasting on IGF-I binding was determined as well. All tissues examined, with the exception of liver and muscle, exhibited specific ${ }^{125} \mathrm{I}-\mathrm{IGF}-\mathrm{I}$ binding to crude membrane preparations (Fig. 3). Specific ${ }^{125}$ I-IGF-I binding was highest in brain and testes, while lung, kidney, and stomach bound slightly lower levels. Specific ${ }^{125}$ I-IGF-I binding to heart membranes was $\sim 1-2 \%$ of total counts, while specific binding to skeletal muscle and liver membranes was $<1 \%$, and ${ }^{125}$ I-IGF-I binding to these latter two tissues was not examined further. $48 \mathrm{~h}$ of fasting resulted in significant increases in ${ }^{125} \mathrm{I}-\mathrm{IGF}-\mathrm{I}$ binding to certain tissue membranes. Kidney, lung, stomach, and testes membranes from fasted rats bound $\sim 30-50 \%$ more IGF-I than those from fed rats. In contrast, brain membrane ${ }^{125} \mathrm{I}-\mathrm{IGF}-\mathrm{I}$ specific binding was not different between fed and fasted rats. Specific ${ }^{125} \mathrm{I}-\mathrm{IGF}-\mathrm{I}$ binding to heart membranes, although low relative to other tissues,

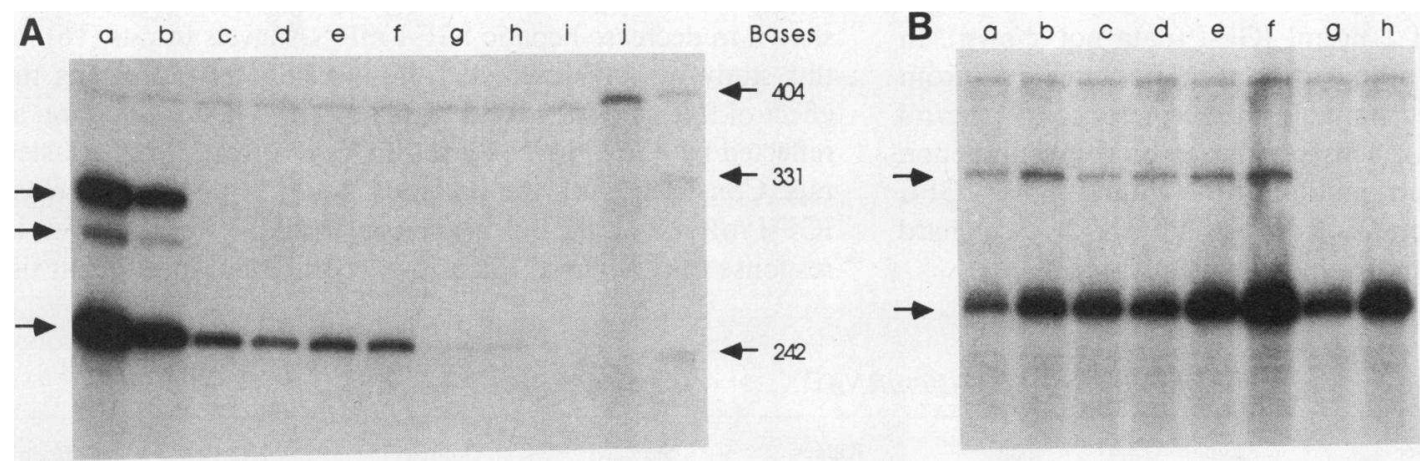

Figure 2. Regulation by fasting of the expression of alternative 5 '-untranslated regions present in transcripts of the rat IGF-I gene. The solution hybridization/ RNase protection assay was performed using the IGF-I antisense RNA which detects IGF-I mRNAs with the different 5 '-untranslated regions as described in

Methods. $(A) 10 \mu \mathrm{g}$ of total RNA (as determined by absorbance at $260 \mathrm{~nm}$ ) from fed liver (lane $a$ ), fasted liver (lane $b$ ), fed testis (lane $c$ ), fasted testis (lane $d$ ), fed heart (lane $e$ ), fasted heart (lane $f$ ), fed brain (lane $g$ ), fasted brain (lane $h$ ), probe alone with RNase (lane $i$ ), and probe alone without RNase (lane $j$ ) were used in the assay. The three arrows indicate, from top to bottom, IGF-I mRNAs with the class A, B, and C 5'-untranslated regions, respectively. A ${ }^{32}$ P-end labeled Hpa II digest of pUC-19 was used as a size marker. (B) $10 \mu \mathrm{g}$ of total RNA from fasted kidney (lane $a$ ), fed kidney (lane $b$ ), fasted stomach (lane $c$ ), fed stomach (lane $d$ ), fasted lung (lane $e$ ), fed lung (lane $f$ ), fasted muscle (lane $g$ ), and fed muscle (lane $h$ ) were used in the assay. The upper and lower arrows represent IGF-I mRNAs with the class A and C 5'-untranslated regions, respectively. 
Table I. Effect of Fasting on Expression of Alternative 5'-Untranslated Regions Present in Transcripts of the Rat IGF-I Gene

\begin{tabular}{|c|c|c|c|c|c|c|c|c|}
\hline IGF-I transcript & Liver & Lung & Testis & Kidney & Stomach & Muscle & Heart & Brain \\
\hline Class A & $5.2 \pm 2.9$ & $2.5 \pm 0.7$ & $1.6 \pm 0.3$ & $1.8 \pm 0.1$ & $1.8 \pm 0.6$ & & & \\
\hline Class B & $7.9 \pm 5.0$ & & & & & & & \\
\hline Class C & $9.8 \pm 8.3$ & $6.1 \pm 3.1$ & $1.5 \pm 0.2$ & $2.1 \pm 0.4$ & $1.6 \pm 0.5$ & $3.0 \pm 0.5$ & $1.1 \pm 0.2$ & $1.7 \pm 0.4$ \\
\hline
\end{tabular}

Values represent the mean fold difference \pm SEM in the particular IGF-I 5 -untranslated region-specific band in the fed as opposed to fasted rats. Each value represents the mean difference as determined from the levels in three preparations of RNA prepared from three separate rats from each nutritional group, performed in duplicate.

did exhibit a 2.5 -fold increase in fasted as compared with fed animals.

To ascribe fasting-induced increases in specific ${ }^{125} \mathrm{I}-\mathrm{IGF}-\mathrm{I}$ binding to changes in receptor affinity and/or receptor number, competition/inhibition experiments were conducted (Fig. 4 and Table III). When the data were plotted according to the method of Scatchard (32) to calculate $R_{0}$ and $K_{\mathrm{d}}$, a straight line was obtained consistent with a single class of binding sites (data not shown). Interestingly, however, variable results were seen in the different tissues (Table III). In the kidney and stomach the affinity for IGF-I was similar in fasted and fed rats, suggesting that the increased binding was due to an increase in receptor number. In contrast, in the lung and testes the affinity for IGF-I was higher in fasted as opposed to fed rats, suggesting that the increase in binding to these tissues from fasted rats was due, at least in part, to an increase in receptor affinity. Of note, in both lung and testes the competition/inhibition experiments demonstrated a paradoxical increase in ${ }^{125} \mathrm{I}$-IGF-I binding in the presence of low concentrations of unlabeled peptide (the so-called "hook" phenomenon) to membrane preparations from fed animals (e.g., lung in Fig. 4). With fasting this increase in ${ }^{125} \mathrm{I}-\mathrm{IGF}-\mathrm{I}$ binding in the presence of low concentrations of unlabeled peptide essentially disappeared. In cultured cells this hook phenomenon has been ascribed to the presence of a membrane-associated IGF-binding protein (33). Of interest, in those previous studies the IGFbinding protein both increased ${ }^{125}$ I-IGF-I binding at low concentrations of unlabeled peptide and decreased the apparent affinity of the IGF-I receptor for IGF-I. In heart, ${ }^{125}$ I-IGF-I binding to membranes prepared from fed animals increased $65 \%$ in the presence of $1 \mathrm{ng} / \mathrm{ml} \mathrm{IGF-I} \mathrm{(data} \mathrm{not} \mathrm{shown).} \mathrm{In}$ contrast, ${ }^{125} \mathrm{I}-\mathrm{IGF}-\mathrm{I}$ binding to membranes prepared from fasted animals increased only $5 \%$ in the presence of $1 \mathrm{ng} / \mathrm{ml}$ IGF-I (data not shown). This significant hook phenomenon precluded accurate determination of the $K_{d}$ and $R_{0}$ for IGF-I binding to heart membranes from fed animals by Scatchard analysis of the competition/inhibition data.
The effect of fasting on the expression of IGF-I receptors was further examined by determining IGF-I receptor mRNA levels in the tissues from fed and fasted rats. Hybridization of a ${ }^{32} \mathrm{P}$-labeled human IGF-I receptor cDNA to Northern blots of total RNA prepared from tissues from fed and fasted rats demonstrated a hybridizing band $11 \mathrm{~kb}$ in length (Fig. 5). This band is similar to that which has been reported previously in rat tissues (27). Similarly, when a Northern blot of total RNA from rat granulosa cells was hybridized to the ${ }^{32} \mathrm{P}$-labeled rat IGF-I receptor cDNA, a band $11 \mathrm{~kb}$ in length was seen (data not shown). To more accurately quantitate the apparent differences in IGF-I receptor mRNA levels seen in some tissues by Northern blot analysis (Fig. 5), a 575-base rat IGF-I receptor antisense RNA was used in the solution hybridization/ RNase protection assay. Using this assay, a single protected band 575 bases in length was seen (Fig. 6). IGF-I receptor mRNA levels were quantitated in the lung, brain, heart, kidney, testis, and stomach (Fig. 7). In kidney, stomach, and heart fasting resulted in a $\sim 2$ - to 2.5 -fold increase in IGF-I receptor mRNA levels. In lung IGF-I receptor mRNA levels increased 1.6-fold in response to fasting, whereas in brain and testis little to no change in IGF-I receptor mRNA levels was seen in fasted as compared with fed tissues.

\section{Discussion}

Previous studies have demonstrated that nutritional alterations result in decreased plașma IGF-I levels in rats as well as humans $(10,11)$. Consistent with the idea that the liver is the source of the majority of circulating IGF-I, fasting has been shown to decrease hepatic IGF-I mRNA levels in rats (16). In this study we have extended those results by examining the effect of fasting on the local regulation of IGF-I production as reflected by IGF-I mRNA levels in tissues from fed and fasted rats. Consistent with the previous study, fasting did decrease IGF-I mRNA levels, but the change in IGF-I mRNA levels in response to fasting was quantitatively different in different tis-

Table II. Effect of Fasting on Expression of IGF-Ia and IGF-Ib mRNAs

\begin{tabular}{ccccccccc}
\hline IGF-I transcript & Liver & Lung & Testis & Kidney & Stomach & Muscle & Heart & Brain \\
\hline IGF-Ib & $16.5 \pm 8.3$ & $7.0 \pm 1.8$ & $2.1 \pm 0.2$ & $3.7 \pm 1.3$ & $1.8 \pm 0.6$ & $2.1 \pm 0.4$ & $1.0 \pm 0.1$ & $1.7 \pm 1.2$ \\
IGF-Ia & $6.0 \pm 3.7$ & $7.4 \pm 3.2$ & $1.4 \pm 0.1$ & $3.2 \pm 0.9$ & $1.4 \pm 0.3$ & $2.3 \pm 0.3$ & $1.0 \pm 0.1$ & $1.6 \pm 0.6$
\end{tabular}

Values represent the mean fold difference \pm SEM in IGF-Ia or IGF-Ib mRNA levels in fed as compared with fasted animals. Each value represents the mean difference as determined from the levels in three preparations of RNA prepared from three separate rats from each nutritional group. 


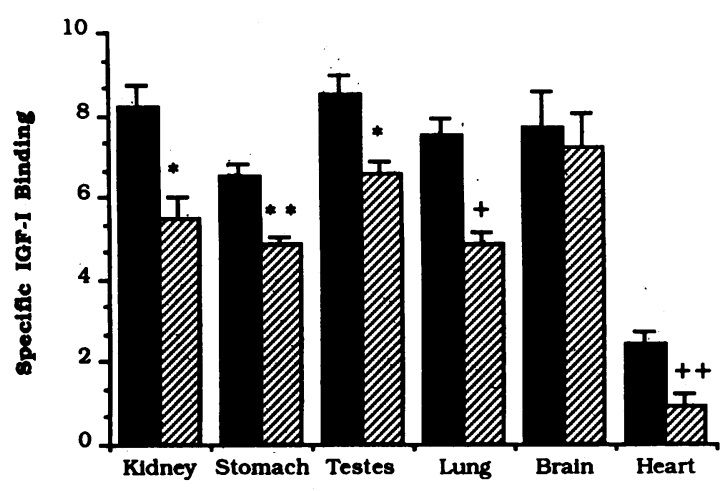

Figure 3. Regulation by fasting of IGF-I binding to crude membrane preparations prepared from fed and fasted tissues. The level of ${ }^{125} \mathrm{I}-$ IGF-I binding to crude membrane preparations prepared from tissues pooled from three fasted (solid bars) and three fed (hatched bars) rats was determined as described under Methods. The values represent the percent total specific binding in the fasted and fed tissues. Each value represents the mean of at least three independent determinations performed in triplicate. ${ }^{*}, P<0.025$; ${ }^{* *}, P<0.005$; ,$+ P<0.01$.

sues in that marked changes in IGF-I mRNA levels were seen in the lung and liver, intermediate changes were seen in the kidney and muscle, and minimal to no change was seen in the stomach, testis, brain, and heart. Fasting also resulted in changes in ${ }^{125} \mathrm{I}-\mathrm{IGF}-\mathrm{I}$ binding. In those tissues in which it was measured, fasting increased this binding, reflecting alterations in IGF-I receptor number and/or affinity in fasted animals. The only exception to this was the brain, in which specific IGF-I binding did not change in response to fasting.

The mechanism by which fasting causes decreased plasma IGF-I levels has not been determined. In rats, GH levels decrease in response to fasting and dietary alterations $(12,13)$, but in addition the administration of $\mathrm{GH}$ to fasted animals does not reverse the decrease in plasma IGF-I levels (14). These and other data demonstrating decreased $\mathrm{GH}$ binding to

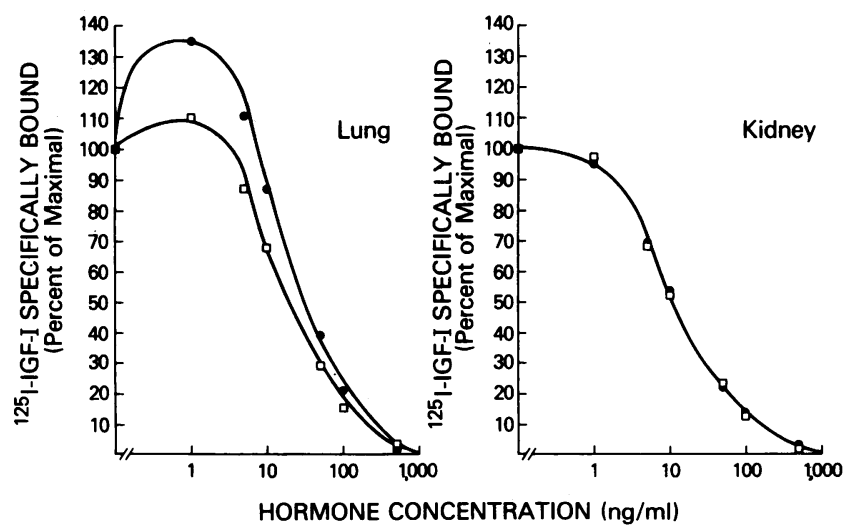

Figure 4. Competition-inhibition of ${ }^{125}$ I-IGF-I binding to lung and kidney membranes from fed and fasted rats by unlabeled IGF-I. Crude membranes from lung and kidney of rats fed ad lib. (solid circles) or fasted for $48 \mathrm{~h}$ (open squares) were incubated with ${ }^{125}$ I-IGF-I and increasing concentrations of unlabeled IGF-I as described in Methods. The percent of maximal specific binding of ${ }^{125}$ I-IGF-I (i.e., that in the absence of unlabeled IGF-I) was determined and plotted against unlabeled IGF-I concentration.
Table III. Effect of Fasting on IGF-I Receptor Number and Affinity

\begin{tabular}{ccc}
\hline Tissue & $R_{0}$ & $K_{\mathrm{d}}$ \\
\hline & pmol/ml per $60 \mu \mathrm{g}$ protein & $n M$ \\
Stomach & & \\
Fast & 0.126 & 1.60 \\
Fed & 0.084 & 1.48 \\
Lung & & \\
Fast & 0.207 & 2.18 \\
Fed & 0.168 & 3.26 \\
Brain & & \\
Fast & 0.161 & 1.90 \\
Fed & 0.155 & 1.93 \\
Testes & & \\
Fast & 0.131 & 1.23 \\
Fed & 0.234 & 3.32 \\
Kidney & 0.178 & 1.69 \\
Fast & 0.139 & 1.89 \\
Fed & &
\end{tabular}

Binding constants were calculated by linear regression on data obtained from Scatchard analysis of competition/inhibition assays performed under Methods.

livers from fasted rats (11) have led to the speculation that fasting induces a $\mathrm{GH}$-resistant state which results in a decrease in plasma IGF-I levels $(10,11,14)$. For the following reasons, the results of this study suggest that in addition to $\mathrm{GH}$, other factors are also responsible for the changes in IGF-I production during fasting. (a) A previous study has shown that IGF-I mRNA levels in the heart are GH responsive (8); despite that, no changes in IGF-I mRNA levels in the heart were seen in the fasted animals. (b) Fasting resulted in coordinate regulation of the expression of IGF-I mRNAs with the different 5'-untranslated regions. This pattern of regulation by fasting is different than the differential pattern of regulation seen in response to $\mathrm{GH}$ treatment (8). Those factors other than $\mathrm{GH}$ that control IGF-I mRNA levels during fasting are yet to be elucidated, but some of these factors may be systemic factors that mediate a decrease in IGF-I mRNA levels in most tissues. In addition, however, the differences in the magnitude of the decrease of IGF-I mRNA levels in response to fasting (e.g., a $\sim 5$-fold decrease in liver and lung vs. no change in heart or a $\sim 1.6-$ fold decrease in brain and testis) suggest that local factors may be modulating IGF-I mRNA levels as well.

Also of interest in this study were the alterations in IGF-I binding induced by fasting. As noted, IGF-I binding was increased in all of the tissues in which it was measured, except for the brain. This is similar to the changes in insulin binding seen in fasted animals (34). This upregulation of insulin binding is thought to be secondary to decreased plasma insulin levels, while the lack of change in brain insulin binding is apparently due to an insensitivity of brain insulin receptors to plasma insulin levels $(35,36)$. IGF-I is also known to regulate IGF-I binding (37), so the increase in IGF-I binding in tissues from fasted rats may reflect the decrease in plasma IGF-I levels seen in fasted rats, while the lack of change in brain IGF-I binding may, again in analogy to the insulin receptor system, reflect an insensitivity of brain IGF-I receptors to plasma IGF-I levels. This suggests that plasma IGF-I, in addition to locally pro- 


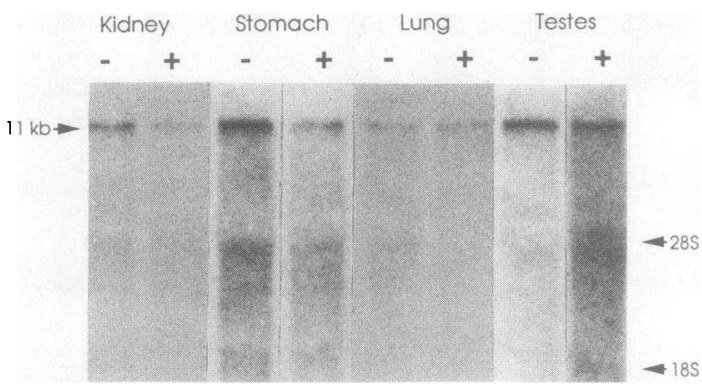

Figure 5. Northern blot analysis of IGF-I receptor mRNA levels in tissues from fasted and fed rats. $15 \mu \mathrm{g}$ of total RNA from the indicated tissues from fasted $(-)$ and fed $(+)$ rats were size-separated by electrophoresis through a $1.2 \%$ agarose-formaldehyde gel and transferred to a nylon membrane that was hybridized to a ${ }^{32} \mathrm{P}$-labeled human IGF-I receptor cDNA. The washed blots were exposed to Kodak X-Omat AR film for either $3 \mathrm{~h}$ (kidney and lung), $2 \mathrm{~d}$ (stomach), or $5 \mathrm{~d}$ (testis). The hybridizing band $11 \mathrm{~kb}$ in length as well as the position of the $28 \mathrm{~S}$ and $18 \mathrm{~S}$ ribosomal bands are indicated.

duced IGF-I, regulates IGF-I binding, since similar changes in IGF-I binding were seen in tissues in which IGF-I mRNA levels changed markedly in response to fasting (e.g., the lung) as well as in tissues in which IGF-I mRNA levels changed minimally or not at all in response to fasting (e.g., the heart). Since tissue IGF-I peptide levels were not measured, however, the degree to which the change in tissue IGF-I mRNA levels reflects the change in tissue peptide levels remains to be explored.

This increase in IGF-I binding noted in various tissues was reflected by an increase in IGF-I receptor mRNA levels in certain tissues as well. Interestingly, in those tissues in which the increase in IGF-I binding was accompanied by an apparent increase in IGF-I receptor number (i.e., stomach, lung, and kidney), IGF-I receptor mRNA levels increased, whereas in those tissues in which IGF-I receptor number was unchanged (i.e., brain and testis), no change in IGF-I receptor mRNA levels was seen. The factors that regulate IGF-I receptor mRNA levels are yet to be determined, but this increase in
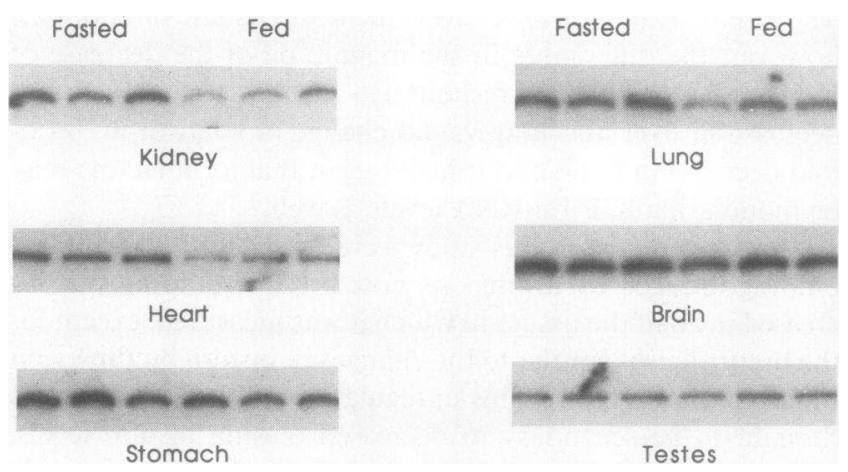

Testes

Figure 6. Regulation by fasting of IGF-I receptor mRNA levels. A solution hybridization/RNase protection assay was performed using the rat IGF-I receptor antisense RNA as described in Methods. $10 \mu \mathrm{g}$ of total RNA (as determined by absorbance at $260 \mathrm{~nm}$ ) prepared from the indicated tissues from fasted (lanes 1-3) and fed (lanes 4-6) rats were used in the assay. Represented is the 575-base protected band present in the different tissues. Each lane represents the results obtained with a separate preparation of RNA, each of which was prepared from a different animal.

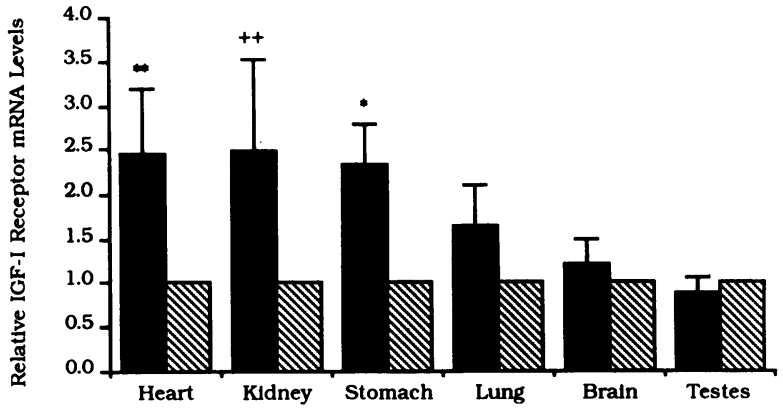

Figure 7. Relative levels of IGF-I receptor mRNA in tissues from fasted and fed rats. IGF-I receptor mRNA levels in tissues from fasted (solid bars) and fed (hatched bars) rats were determined using a solution hybridization/RNase protection assay. The values shown represent the relative IGF-I receptor mRNA levels in the fasted as compared with the fed tissue. In each case the level of IGF-I receptor mRNA in the fed tissue was adjusted to 1.0 , and the level in the fasted tissue was normalized accordingly. The values do not reflect, therefore, tissue to tissue differences in IGF-I receptor mRNA levels. The value for each tissue from fed and fasted animals represents the mean of the level in two separate assays, each done on three different RNA preparations prepared from different animals. ${ }^{*}, P<0.005 ;{ }^{* *}$, $P<0.025 ;++, P<0.05$.

IGF-I receptor mRNA levels may be secondary to the decreased plasma IGF-I levels seen in fasted rats. Of note, the change in IGF-I mRNA and IGF-I receptor mRNA levels in the tissues from fasted and fed rats was not coordinate. This suggests that factors present in the plasma or tissues of fasted animals may regulate expression of the genes encoding IGF-I and its receptor in a discoordinate fashion.

Finally, as noted, several studies have demonstrated a marked decrease in plasma IGF-I levels in rats fasted for 24-72 $\mathrm{h}$ (11). It has been suggested that this decrease in plasma IGF-I levels may be part of an adaptive mechanism by the body to shunt calories away from nonessential processes, including growth, during periods of malnutrition (38). The measurement of greatest importance, however, within a given tissue, is IGF-I action. While local IGF-I production may, through an autocrine/paracrine action, mediate some of the actions of $\mathrm{GH}$ $(39,40)$, as well as be involved in tissue growth, repair, and regeneration (18-20), it may also influence a spectrum of specialized cell functions. Some of these include augmenting human chorionic gonadotropin-luteinizing hormone-stimulated testosterone production by cultured testicular cells, potentiating the effects of follicle-stimulating hormone on the induction of luteinizing hormone receptors and aromatase activity in granulosa cells, stimulating proteoglycan synthesis by endothelial cells, and stimulating myoblast and adipocyte differentiation (21-24). Furthermore, a previous study has demonstrated that in perfused rat hearts a preparation of nonsuppressible insulin-like activity (which probably included IGF-I and IGF-II) was as potent as insulin in stimulating glucose uptake and lactate production, suggesting that in the heart IGF-I may mediate metabolic effects (41). Given these specialized functions of IGF-I, IGF-I action within a given tissue may or may not be altered by fasting, depending on whether its specialized function is preserved. There is, at present, no direct measure of in vivo IGF-I action in different tissues available, but in this study two of the factors that influence IGF-I action, ligand availability, as reflected by tissue IGF-I mRNA levels, 
and receptor availability, have been measured. If the changes in tissue IGF-I mRNA levels reflect changes in tissue IGF-I peptide levels, then, taken together with the uniform increase in IGF-I binding (except in brain), the results of this study suggest that there may be differential changes in IGF-I action in various tissues during fasting.

In conclusion, the response of IGF-I and IGF-I receptor mRNA levels to fasting is quantitatively different in different tissues. Further study of the regulation of these mRNA levels, IGF-I binding, and IGF-I production in fed and fasted rats will hopefully facilitate elucidation of the role of local IGF-I production, the systemic and local factors that regulate IGF-I biosynthesis, and the regulation of IGF-I action in different tissues.

\section{Acknowledgments}

We are grateful to Dr. Axel Ullrich for providing the human IGF-I receptor cDNA. We would like to thank Dr. Takashi Kadowaki for his critical reading of the manuscript and his helpful suggestions. We would also like to thank Violet Katz and Cherie Frieberg for their secretarial assistance.

\section{References}

1. Humbel, R. E. 1984. Insulin-like growth factors, somatomedins, and multiplication stimulating activity: chemistry. In Hormonal Proteins and Peptides. Vol. XII. C. H. Li, editor. Academic Press, Inc., New York. 57-79.

2. Jansen, M., F. M. A. van Schaik, A. T. Ricker, B. Bullock, D. E. Woods, K. H. Gabbay, A. L. Nussbaum, J. S. Sussenbach, and J. L. Van den Brande. 1983. Sequence of cDNA encoding human insulinlike growth factor I precursor. Nature (Lond.). 306:609-611.

3. Bell, G. I., M. M. Stempien, N. M. Fong, and L. B. Rall. 1986. Sequences of liver cDNAs encoding two different mouse insulin-like growth factor I precursors. Nucleic Acids Res. 14:7873-7882.

4. Roberts, C. T., Jr., S. R. Lasky, W. L. Lowe, Jr., W. T. Seaman, and D. LeRoith. 1987. Molecular cloning of rat insulin-like growth factor I complementary deoxyribonucleic acids: differential messenger ribonucleic acid processing and regulation by growth hormone in extrahepatic tissues. Mol. Endocrinol. 1:243-248.

5. Roberts, C. T., Jr., S. R. Lasky, W. L. Lowe, Jr., and D. LeRoith. 1987. Rat IGF-I cDNAs contain multiple 5'-untranslated regions. Biochem. Biophys. Res. Commun. 146:1154-1159.

6. Shimatsu, A., and P. Rotwein. 1987. Mosaic evolution of the insulin-like growth factors: organization, sequence, and expression of the rat insulin-like growth factor I gene. J. Biol. Chem. 262:78947900.

7. Shimatsu, A., and P. Rotwein. 1987. Sequence of two rat insulin-like growth factor I mRNAs differing within the 5'-untranslated region. Nucleic Acids Res. 15:7196.

8. Lowe, W. L., Jr., C. T. Roberts, Jr., S. R. Lasky, and D. LeRoith. 1987. Differential expression of alternative 5 -untranslated regions in mRNAs encoding rat insulin-like growth factor I. Proc. Natl. Acad. Sci. USA. 84:8946-8950.

9. Van Wyk, J. J. 1984. The somatomedins: biological actions and physiological control mechanisms. In Hormonal Proteins and Peptides. Vol. XII. C. H. Li, editor. Academic Press, Inc. New York. 82-125.

10. Phillips, L. S., and T. G. Unterman. 1984. Somatomedin activity in disorders of nutrition and metabolism. Clin. Endocrinol. Metab. 13:145-189.

11. Underwood, L. E., D. R. Clemmons, M. Maes, A. J. D'Ercole, and J.-M. Ketelslegers. 1986. Regulation of somatomedin-C/insulinlike growth factor I by nutrients. Horm. Res. (Basel). 24:166-176.

12. Schalch, D. S., and T. C. Cree. 1985. Protein utilization in growth: effect of calorie deficiency on serum growth hormone, somatomedins, total thyroxine $\left(\mathrm{T}_{4}\right)$ and triiodothyronine, free $\mathrm{T}_{4}$ index and total corticosterone. Endocrinology. 117:2307-2312.

13. Cree, T. C., and D. S. Schalch. 1985. Protein utilization in growth: effect of lysine deficiency on serum growth hormone, somatomedins, insulin, total thyroxine $\left(T_{4}\right)$ and triiodothyronine, free $T_{4}$ index, and total corticosterone. Endocrinology. 117:667-673.

14. Maes, M., Y. Amand, L. E. Underwood, D. Maiter, and J.-M. Ketelslegers. 1988. Decreased serum insulin-like growth factor I response to growth hormone in hypophysectomized rats fed a low protein diet: evidence for a post-receptor defect. Acta Endocrinol. 117:320-326.

15. Froesch, E. R., C. Schmid, J. Schwander, and J. Zapf. 1985. Actions of insulin-like growth factors. Annu. Rev. Physiol. 47:443-467.

16. Emler, C. A., and D. S. Schalch. 1987. Nutritionally-induced changes in hepatic insulin-like growth factor I (IGF-I) gene expression in rats. Endocrinology. 120:832-834.

17. D'Ercole, A. J., A. D. Stiles, and L. E. Underwood. 1984. Tissue concentrations of somatomedin C: further evidence for multiple sites of synthesis and paracrine or autocrine mechanisms of action. Proc. Natl. Acad. Sci. USA. 81:935-939.

18. Jennische, E., A. Skottner, and H.-A. Hansson. 1987. Dynamic changes in insulin-like growth factor I immunoreactivity correleate to repair events in rat ear after freeze-thaw injury. Exp. Mol. Pathol. 47:193-201.

19. Jennische, E., A. Skottner, and H.-A. Hansson. 1987. Satellite cells express the trophic factor IGF-I in regenerating skeletal muscle. Acta Physiol. Scand. 129:9-15.

20. Stiles, A. D., I. R. S. Sosenko, A. J. D'Ercole, and B. T. Smith. 1985. Relation of kidney tissue somatomedin-C/insulin-like growth factor I to postnephrectomy renal growth in the rat. Endocrinology. 117:2397-2401.

21. Kasson, B. G., and A. J. W. Hsueh. 1987. Insulin-like growth factor I augments gonadotropin-stimulated androgen biosynthesis by cultured rat testicular cells. Mol. Cell. Endocrinol. 52:27-34.

22. Bar, R. S., B. L. Dake, and S. Stueck. 1987. Stimulation of proteoglycans by IGF-I and IGF-II in microvessel and large vessel endothelial cells. Am. J. Physiol. 253:E21-E27.

23. Florini, J. R., D. Z. Ewton, S. L. Falen, and J. J. Van Wyk. 1986. Biphasic concentration dependency of stimulation of myoblast differentiation by somatomedins. Am. J. Physiol. 250:C771-C778.

24. Smith, P. J., L. S. Wise, R. Berkowitz, C. Wan, and C. S. Rubin. 1988. Insulin-like growth factor $I$ is an essential regulator of the differentiation of 3T3-L1 adipocytes. J. Biol. Chem. 263:9402-9408.

25. Cathala, G., J.-F. Savouret, B. Mendez, B. L. West, M. Karin, J. A. Marial, and J. D. Baxter. 1983. A method for the isolation of intact, translationally active ribonucleic acid. DNA (NY). 2:329-336.

26. Lowe, W. L., Jr., A. E. Schaffner, C. T. Roberts, Jr., and D. LeRoith. 1987. Developmental regulation of somatostatin gene expression in brain is region specific. Mol. Endocrinol. 1:181-187.

27. Ullrich, A., A. Gray, A. W. Tam, T. Yong-Feng, M. Tsubokawa, C. Collins, W. Henzel, T. Le Bon, S. Kathuria, E. Chen, S. Jacobs, U. Francke, J. Ramachandran, and Y. Fujita-Yamaguchi. 1986. Insulin-like growth factor I receptor primary structure: comparison with insulin receptor suggests structural determinants that define functional specificity. EMBO (Eur. Mol. Biol. Organ.) J. 5:2503-2512.

28. Lowe, W. L., Jr., S. R. Lasky, D. LeRoith, and C. T. Roberts, Jr. 1988. Distribution and regulation of rat insulin-like growth factor $I$ messenger ribonucleic acids encoding alternative carboxyterminal Epeptides: evidence for differential processing and regulation in liver. Mol. Endocrinol. 2:528-535.

29. Feinberg, A. P., and B. Vogelstein. 1983. A technique for radiolabeling DNA restriction endonuclease fragments to high specific activity. Anal. Biochem. 132:6-13.

30. Havrankova, J., J. Roth, and M. Brownstein. 1979. Insulin receptors are widely distributed in the central nervous system of the rat. Nature (Lond.). 272:827-829.

31. Lowry, O. H., N. J. Rosebrough, A. L. Farr, and R. J. Randall. 
1951. Protein measurement with Folin phenol reagent. J. Biol. Chem. 193:265-268.

32. Scatchard, G. 1949. The attractions of protein for small molecules and ions. Ann. NY Acad. Sci. 51:660-672.

33. Clemmons, D. R., V. K. M. Han, R. G. Elgin, and A. J. D'Ercole. 1987. Alterations in the synthesis of a fibroblast surface associated $35 \mathrm{~K}$ protein modulates the binding of somatomedin-C/insulin-like growth factor I. Mol. Endocrinol. 1:339-347.

34. Simon, J., R. W. Rosebrough, J. P. McMurtry, N. C. Steele, J. Roth, M. Adamo, and D. LeRoith. 1986. Fasting and refeeding alter the insulin receptor tyrosine kinase in chicken liver but fail to affect brain insulin receptors. J. Biol. Chem. 261:17081-17088.

35. Havrankova, J., J. Roth, and M. J. Brownstein. 1979. Concentrations of insulin and insulin receptors in the brain are independent of peripheral insulin levels. Studies of obese and streptozotocin-treated rodents. J. Clin. Invest. 64:636-642.

36. Pacold, S. T., and W. G. Blackard. 1979. Central nervous system insulin receptors in normal and diabetic rats. Endocrinology. 105:1452-1457.
37. Watanabe, N., R. G. Rosenfeld, R. L. Hintz, L. A. Dollar, and R. L. Smith. 1985. Characterization of a specific insulin-like growth factor-I/somatomedin-C receptor on high density, primary monolayer cultures of bovine articular chondrocytes: regulation of receptor concentration by somatomedin, insulin, and growth hormone. J. Endocrinol. 107:275-283.

38. Phillips, L. S. 1986. Nutrition, somatomedins, and the brain. Clin. Exp. Metab. 35:78-87.

39. Schlechter, N. L., S. M. Russell, E. M. Spencer, and C. S. Nicoll. 1986. Evidence suggesting that the direct growth promoting effect of growth hormone on cartilage in vivo is mediated by local production of somatomedin. Proc. Natl. Acad. Sci. USA. 83:7932-7934.

40. Nilsson, A., J. Isgaard, A. Lindahl, A. Dahlstrom, A. Skottner, and O. G. P. Isaksson. 1986. Regulation by growth hormone of number of chondrocytes containing IGF-I in rat growth plate. Science (Wash. DC). 233:571-574.

41. Meuli, C., and E. R. Froesch. 1975. Effects of insulin and of NSILA-S on the perfused rat heart: glucose uptake, lactate production, and efflux of 3-O-methyl glucose. Eur. J. Clin. Invest. 5:93-99. 